\title{
The Impact of Common Agricultural Policy of EU on Regional Growth and Convergence
}

\section{Ivana KRAFTOVÁ, Jaroslav KOVÁRNÍK}

\begin{abstract}
The aim of this article is to show the influence of common agricultural policy on the member states of the EU in relationship with the regional policy viewed as cohesion and growth supporting policy. This article focuses on the development of efficiency of old and new EU member states in the last decade.
\end{abstract}

KEYWORDS: Common agricultural policy of EU, Cohesion regional policy of EU, Unit efficiency of agriculture subsidies

JEL Classification: Q18, R11, R58

\section{INTRODUCTION}

The common agricultural policy of the EU has already undergone several reforms, resulting in the fact that this policy loses its single-branch characteristics. In spite of the decrease in the relative share of the resources from the budget of the EU, the absolute amounts of money are increasing. Whereas $80 \%$ of areas of countries in the EU are rural regions, a legitimate question arises, whether the support of agriculture is connected with the aims of regional policy of the EU.

The 1957 Treaty of Rome established five basic aims in the area of agriculture to fulfill the correct operation of EHS in this area. These five includes: (ES 1957)

- increase productivity of agriculture by supporting technological progress and by ensuring rational development of agricultural production and optimal use of production factors, especially labor force;

- ensure the appropriate standard of living of agricultural population by increasing individual revenues of people from agricultural sector;

- $\quad$ stabilize the markets;

- ensure continuous supply;

- ensure reasonable prices of delivery for customers.

Based on the above-mentioned goals, three basic principles were formulated in the treaty of 1962, which are applied even in current European agricultural policy. These principles characterize the common agricultural market and embody the cornerstone of current EU common agricultural policy (Moussis, 2008):

1. Market unity. This principle presents free movement of agricultural products within the similar conditions as on the internal market. This principle also assumes the uniform agricultural prices in the whole EU. In practice, it means cancellation of protective tools for trade reduction, such as

Ivana Kraftová is Associate Professor in the Faculty of Economics and Administration at the University of Pardubice, Czech Republic. She has published numerous articles in financial management and public sector economics. Her recent research focuses on mesoeconomic issues in the context of regional development.

Jaroslav Kovárník is Assistant Professor in the Faculty of Informatics and Management, Department of Economics, at the University of Hradec Kralove, Czech Republic. He specializes on regional policy and development. 
duties, taxes, import and export quotas, and other trade restrictions, all of them with equivalent efficacy.

2. Community preference. This principle creates protection of common European market, and prefers products of European origin at the expense of the imported products. The reason for this preference is the protection of internal market from cheaper imports and excessive fluctuation of world trade.

3. Financial solidarity. This principle is realized by European Agricultural Guarantee Fund. All member states participate jointly on measures and financial consequences of common agricultural policy. Some states are in position of net recipient and some in position of net provider of the resources from common agricultural policy in the EU. The largest recipients of European agricultural subsidies are Greece, Poland and Spain, the biggest provider is Germany, followed by Italy. As for the recalculation on one inhabitant, the situation is quite different. In this point of view, the largest providers are Luxembourg, Belgium and the Netherlands. On the other side of the spectrum, Greece and Ireland are in position of largest recipients on one inhabitant. In connection to the endowment agricultural policy, every inhabitant of EU $15^{1}$ provides six euro to EU $12^{2}$ (Králová, 2011).

In line with the above-mentioned facts, there are some moments that could be analyzed not only from the point of view of agricultural support, but also as the tool of policy of regional growth and cohesion support.

Table 1: Common Agricultural Policy Expenditure Shares in the EU Budget, 1960 - 2011

\begin{tabular}{|r|r|r|r|}
\hline \multirow{2}{*}{ Year } & \multicolumn{1}{|c|}{ Total Expenditure } & \multicolumn{2}{|c|}{ Common Agricultural Policy } \\
\cline { 2 - 4 } & $\begin{array}{c}\text { mil. ECU, resp. mil. } \\
\text { EUR }\end{array}$ & $\begin{array}{c}\text { mil. ECU, resp. mil. } \\
\text { EUR }\end{array}$ & \multicolumn{2}{c|}{$\begin{array}{c}\text { Percentage } \\
\text { Shares }\end{array}$} \\
\hline 1960 & 58.6 & - & 0 \\
\hline 1965 & 339 & 28.7 & 8.5 \\
\hline 1970 & 3576.4 & 3166.0 & 88.5 \\
\hline 1980 & 16454.8 & 11606.5 & 70.5 \\
\hline 1990 & 45608.0 & 28919.5 & 63.4 \\
\hline 1999 & 86908.1 & 39771.0 & 45.8 \\
\hline 2000 & 89440.6 & 41469.0 & 46.4 \\
\hline 2001 & 92569.4 & 43697.7 & 47.2 \\
\hline 2005 & 106300.0 & 53059.5 & 49.9 \\
\hline 2006 & 111969.0 & 54541.3 & 48.7 \\
\hline 2007 & 125816.6 & 52440.6 & 41.7 \\
\hline 2008 & 129149.6 & 53701.7 & 41.6 \\
\hline 2009 & 133845.9 & 54680.2 & 40.9 \\
\hline 2010 & 141453.0 & 57780.4 & 40.9 \\
\hline 2011 & 141900.0 & 57292.1 & 40.4 \\
\hline
\end{tabular}

Source: Authors’ calculations based on (EC, 2011) data.

Despite the fact that the share of common agricultural policy in the expenditure of the EU budget has been decreasing in recent years, this policy is still the most important common policy of EU, and it uses a significant part of European resources, as presented in Table 1. This table shows that the percentage share of common agricultural policy in the total budget of EU has been on a gradual

\footnotetext{
${ }^{1}$ EU 15 = Austria, Belgium, Denmark, Finland, France, Germany, Greece, Ireland, Italy, Luxembourg, Netherlands, Portugal, Spain, Sweden, United Kingdom.

${ }^{2}$ EU 12 = Bulgaria, Cyprus, Czech Republic, Estonia, Hungary, Latvia, Lithuania, Malta, Poland, Romania, Slovakia, Slovenia.
} 
relative decrease between the years 1960 - 2011, and currently it presents around $40 \%$ of the total budgeted sum. On the other hand, there has been an increase of total budgeted resources of EU, together with the increase of financial resources, which are allocated directly or indirectly into agriculture. In connection with agricultural policy, it is thus possible to speak about the relative decrease, but an absolute increase in financial resources.

While in 1965, when the common agricultural policy was formulated and started to assert, there were only $8.5 \%$ of the budget allocated to the field of agriculture, in the overproduction period of 1970s and 1980s, the share of common agricultural policy on the EU budget has risen to $88.5 \%$ and $70.5 \%$ respectively. This may serve as an indicator that the first reform steps in the field of common agricultural policy were not that much successful. However, it is necessary to mention that Greece became a member in 1981 and Spain and Portugal in 1986 - all of these countries have large, but undeveloped agrarian sector. A significant decrease appeared in 1999, when the share of common agricultural policy on the EU budget dropped to $45.8 \%$. Since 2005, there has been a steady slight decline and in recent years, the share is kept under the level of $41 \%$ of the total budgeted sum.

\section{ANALYSIS STARTING POINTS}

\subsection{OECD Link for Agricultural Support}

During the evaluation of agricultural support and its regional impacts, it is not possible to focus only on common agricultural policy of EU. The Organization for Economic Co-operation and Development, created in 1961 with the basic aim of supporting economic development and economic cooperation worldwide, has an important role in the relationship with the agriculture activity as well. OECD covers practically all areas of economic policy - from environment and development cooperation, employment and social areas, over trade, public administration, science, technology, industry, transport, to agriculture and fishery.

As a result of the OECD activity in agriculture, systems of certification of some agricultural commodities are created, general principles for consideration of environmental aspects are accepted, import restrictions and export supports of agricultural products are reviewed, standards of technical parameters for agricultural and forestry machinery are introduced, and general indicators for more relevant comparison of agricultural policies evaluation are defined (Horáková, 2011).

Nowadays, another important issue is to arrange coherence among development policies in different countries and their regions. This means to ensure that the external impacts of policies of developed countries will not have negative influence on the results of international development cooperation. Kaplan, for instance, claims that “... there is no point in providing development aid to rural areas, when this effort is overbalanced by negative impacts of agricultural subsidies and high protectionist measures in developed countries." (Kaplan,2008). The wide range of agricultural support provided yearly by the OECD serves as evidence that this concern is not false. It is estimated, that the Producer Support Estimate between the years 1986 - 2009 amounted about 220 - 280 billion USD yearly, General Services Support amounted 22 - 38 billion USD, and Total Support was estimated somewhere between 227 and 383 billion USD, while the highest amount (more than 383 billion USD) was provided in 2009 - the year of deep economic recession (OECD, 2010).

\subsection{Reforming Steps in Common Agricultural Policy of EU}

Up to the 1980s, the common agricultural policy was very successful in fulfilling its goals. However, in the following years, two factors appeared - an increase in agricultural production and lack of Europe's own consumption. At the beginning of 1990s, EU had to deal with the overproduction of the main agricultural products - the so-called overproduction crisis. This led to a number of reforms that should gradually form a new common agricultural policy of EU (EK, 2010). It is obvious that in these 
reforms a trend towards linking with the aims of regional policy is reflected. The most important reforms of common agricultural policy include:

1. The Plan of Mansholt (1968), which led to the wave of mass protests, especially in France. This plan proposed both the restructuring of agriculture based on support of small farmers who decided to leave agriculture sector, and the decrease in price level, in order to force the less efficient farmers to leave this sector.

2. The Reform of MacSharry (1992), which was a compromise between the commitment to decrease the price of subsidies and the requirement to maintain adequate income for the farmers. The basic aims of this reform were to increase competitiveness of agriculture, decrease overproduction, decrease the financial expenditure, increase balance on the market, and introducing measures of environmental protection and rural support. This reform dealt with four basic areas of production: cereals, oilseeds and pulses, beef, and milk and dairy products. The losses were compensated to the farmers by the method of the so-called direct payments, which were first time ever not related to the quantity of production. These payments were provided to every farmer, who agreed with the initiation of part of their land in the idle state for a specified period. Despite the fact, that this reform led to the significant stabilization of expenditure on common agricultural policy, dramatic decline of inventories, and improvement in the financial position of the farmers (their income increased in the absolute expression), the common agricultural policy was still expensive (increase in resources for direct payments and accompanying measures) and administratively demanding (PIGP, 2010).

3. Agenda 2000 (1997) responded to the assumed enlargement of EU. The European Commission introduced proposals for changes in the most important agricultural fields, i.e. in the field of main agricultural crops, beef, milk, and wine. This agenda responded to the development in previous years. It focused on the safety of food, on the environment, and on the sustainable development. It was also emphasized that the future of agricultural sector is connected to the balanced development of rural areas, which present $80 \%$ of the whole European region. In Agenda 2000, two basic pillars of common agricultural policy were created and described, namely the policy of market protection and the policy of rural development, which well, corresponds with the European cohesion regional policy (EC, 2004).

At the same time, "The European Model of Agriculture" was described, which should have created a consistent framework for ensuring the future of rural areas and the support for maintaining and creating new working places, This, as a matter of fact, was a tool for supporting agricultural (and often undeveloped) regions. This model was oriented on the following aspects:

- integrated approach to the rural development, in particular, its links with the agricultural development, creation of new income resources and employment;

- focus on multifunctional, various, and competitive agriculture requiring the support of services provided by farmers;

- flexible support of rural development, application of subsidiarity and decentralization principles that collectively aim for consultations on regional, local, and partner levels;

- transparency during program creation and management - simplified basics and accessible legislation.

“The New" Common Agricultural Policy (2003) was accepted by ministers of agriculture of all EU member states on $23^{\text {rd }}$ June 2003 . The most important changes were the sharp reorientation of production to the needs of the market and paying subsidies regardless of production size. Programs supporting ecological agriculture, quality of production, and animal welfare were also emphasized.

The main principles of the new 2003 approach to the common agricultural policy include:

- cross-compliance (compliance with standards in the area of environment, quality, safety of food, and good agricultural practice);

- $\quad$ single farm payment (single payment for a given farm, permanently replacing the set of direct payments with a single one); 
- decoupling (the removal of the link between support and the agricultural production, which allows producers to make independent decisions about the orientation of their agricultural production, and to react on customer demand on the market);

- set aside (the removal of the land from production; farms oriented on ecological agriculture are liberated from this practice);

- modulation (the transfer of some percentage of direct payments to programs of rural development, specifically, it is declared, that “... farms with the yearly payment higher than 5,000 EUR will be receiving gradual reduction (modulation) of these amounts until the year 2013, at first the modulation will amount 3-4 \% and later, since 2007, the share will be $5 \%$ per year" (Bureš, 2004).

In addition, the element of financial discipline is accented - an agricultural advisory system that should help the agricultural producers with implementing of standards. Moreover, rural development is encouraged - for example the support of food quality, welfare, new technologies, young farmers, and small processors (EU Media, 1999).

The reform called Health Check (2008). This reform was intended to ensure control of the functionality of agricultural policy and new challenges for agriculture were defined within its basic framework - for instance the risk management, importance of climate changes, ecological agriculture, biofuels, and water.

Health Check focused on problems of rural development, which is again closely related to the aims of regional policy of the EU. The following steps were formulated and agreed upon:

1. $10 \%$ rate of compulsory modulation, which means the transfer of financial resources from the agricultural business payments to the rural development fund;

2. removal of businesses with the payment between 100,000 - 300,000 EUR from progressive modulation;

3. additional $4 \%$ of progressive modulation for businesses with payments over 300,000 EUR;

4. rate of financing of modulated resources - the basic rate is $75 \%$ from the EU resources, in the regions of convergence $90 \%$ from the EU resources;

5. enlargement of support for sensitive agricultural areas;

6. possibilities of rural development financing, for example an adaptation for climate changes, renewable resources, innovative approaches, biodiversity (MZ, 2010).

Thanks to the reforms, EU common agricultural policy ceases to be a purely sectoral issue. It is the rural development policy that is gradually more often linked to European regional policy focused on growth and convergence of European regions. The aim of this article is to show how the common agricultural policy influences the EU member states in connection with the above-mentioned direction of regional policy. The other aim is to focus on questions of common agricultural policy efficiency in the framework of the fulfillment of the aims of regional policy of EU.

\subsection{Description of Analysis Approach}

The starting point of the analyzed issue was the assessment of genesis of the European agriculture policy and its principles, including the development of resources allocated from the EU budget for agriculture and rural development support. The analysis also focuses on the OECD support framework. By means of document analysis, information comparison and time series processing, the observed facts were deliberately confronted with the aims of European regional policy.

For the evaluation proper of the links between agricultural and regional policy of the EU, an amount of data was processed - based on a brief description of the current direct subsidies system and its characteristics, as well as on other means of support in the framework of common agricultural policy, and complemented by suggestion of the most serious dangers of this system - which were to show the interdependence of both policies; and, to investigate whether the current agricultural policy could 
be considered an element supporting the cohesion regional policy of EU in both its main aspects: namely in convergence and growth.

The comparison of relationship between value added on 1 ha of agricultural land and unit subsidies was carried out on example of countries of $\mathrm{V}^{3}$ (new member states since 2004 which have different parameters of agriculture) and Netherlands, as a country with the highest absolute value of subsidy on 1 ha. The aim of this comparison was to show the differences between absolute unit values and the structure of value added indicator with subsidies - i.e. the differences, which could be described as convergence or non-convergence.

The other subject of interest was the development of efficiency of EU 27 agriculture in traditional and new member states in the past 10 years. As an indicator of efficiency, the relative indicator of wealth creation in the form of gross value added per capita was chosen. In addition to the graphic analysis, an index analysis of the growth of each member state and groups of states is presented, with the aim to determine the rate of uniqueness of defined performance groups of traditional countries or new member states. The simple rates of variability - the variation range and its first difference - were elaborated with the purpose of determining the variability of efficiency of supported agriculture.

Special attention was paid to differences between the most and the less efficient member states of both groups of states in the comparison with the values of EU 27 in the current planning period, again based on the gross value added per capita. The main purpose was to assess the rate of difference both by the criterion of the country membership in the group of traditional or new member states, and by the criterion of the efficiency rate. The character of the growth index convergent or divergent was also determined.

The important factor for fulfilling the research aim was to determine the existence of correlation relationship between the value of direct subsidies and gross value added of agriculture per capita using the Spearman's coefficient of serial correlation for the level of significance equal to 0.05 . In line with this, an indicator of unit efficiency of agricultural subsidies for each of the member states (UEAS) was calculated and evaluated. This indicator is constructed as the share of gross value added per capita and direct subsidies on 1 hectare. In order to use current data, the year 2010 was set as the reference year, in which, moreover, the crisis decline of 2009 that affected agriculture as well, was already overcome (against the claims of the FAO OECD study).

In confrontation with the obtained results, possible paths of development of agriculture support were indicated in context of upcoming changes in common agricultural policy of EU and persistent emphasis on regional policy of coherence in the incoming planning period of $2014-2020$.

\section{IMPACT OF EU COMMON AGRICULTURAL POLICY}

\subsection{Usefulness and the Risk of Support}

In the European Union and also all around the world, no business sector is more regulated and bureaucratically tied than agriculture. This is a result of the relatively complicated system of agricultural aids, whose basic aim used to be the support of production of raw materials for food production. This aim still survives in the form of direct payments - entitlement supports in fact, whose obtaining is increasingly demanding, especially due to the necessity to follow formulated principles of good agricultural practices.

The second program is the rural development, where the elaboration of appropriate project is conditioned by obtaining support. The elaboration and subsequent defense of this project is more

${ }^{3}$ V4 = Visegrad Group - Czech Republic, Hungary, Poland, Slovakia. 
difficult. These are for example the payments for the ecological agriculture, which could vary in different countries, according to the specific natural conditions.

Moreover, many supporting programs are announced of both production and developing nature. Hand to hand with subsidies, many risks accompany the drawing of financial resources. The primary risk is the choice of optimal support structure and high administrative burden of the participation in developing programs. The very orientation in possibilities of obtaining support can become very unclear and much too complicated for project non-specialists. This diverts the focus from the purpose of gaining support towards the support of "project managers" and towards the increase in immanent non-efficiency of subsidies, which instead of removing the imperfections of the market create some of them as well. As it is generally the case in public economics, also here the optimal relationship between efficiency and righteousness is sought.

\section{2 "Fair" System and "Same” Subsidies}

Direct payments represent the foundation of all provided financial support; in the EU 15, the so-called Single Payment Scheme (SPS) is used; in the countries of EU 12, the Single Area Payment Scheme (SAPS) is used, which means a simplified system of direct payments to conventional farmers. SPS and SAPS are of "areal nature". Based on the production size during the reference period of 1996 - 1999, the total fixed amount of financial resources for each state was set. All partial payments were summed and after the calculation, an areal payment for one hectare was determined (Agris, 2009). (The size of this payment is not constant, Czech Republic, for instance, reported the acreage of 3,469 million hectares of agricultural land at the moment of entrance to the EU. However, if the justified acreage is higher in some year, the so-called reduction will be made, which means the yearly national envelope will be divided by new - higher justified acreage. Accordingly, if the justified acreage is lower, only the relative amount will be paid.)

Moreover, additional TOP-UP payments with "commodity nature" are used, as well as payments with "regional aspect" aiming at the support of the mountain and foothill areas, in order to balance their less favorable business conditions. For example the four-zone criteria of Less-Favored Areas (LFA) in the EU were redefined for conditions in the Czech Republic in 2010 (Kučera\&Štolbová, 2010).

Until 2003, these resources were allocated only to farmers who really grew the relevant commodity or bred the specific category of animals. As a result of the undertaken reforms, states could gradually begin to pay these payments to each farmer without the requirement of their exercising the appropriate activity (grow the relevant commodity or breed the specific category of animals). The full disengagement of payments from the production, in other words the decoupling, should be completed in the EU 15 members by the end of 2013. In the newer member states, the payment system is slightly different.

The opinions on subsidiary policy, more precisely on the current adjustment of direct payments, are different, even within the Czech Republic as such. On the one hand, the representatives of professional associations and entrepreneurs emphasize the injustice and disadvantages of current form of agrarian subsidies distribution, on the other hand, the economists argue with different production costs and purchasing power of population in different member states of EU. The agricultural sector is the one with very significant differences in efficiency and costs of agricultural production - these often reach the value of many tens of percent. The truth is that a gradually widening gap opens between reality and the original indicators that were the basis for calculation of subsidies.

After the Lisbon Strategy, EU introduced the 2020 Strategy, which should have brought new perspectives not only into the sector of agriculture. In connection to this strategy, on November 18th 2010, the European Commission presented a large announcement for public discussion called "Common agricultural policy before the year 2020 - the solution of future problems in the fields of food, natural resources, and urban planning”. The options outlining the future of common agricultural 
policy are closely associated with the stimulation of intelligent and sustainable growth, considering the wealth and agricultural diversity of EU 27 countries. The EC announcement “... highlights the importance of redistribution, correction, and better aimed support based on objective and fair criteria, and considering the understandability for the tax payer" (EC, 2010). These criteria should reflect economical aspects (they should have, among other things, the form of income support), as well as environmental aspects (they should reflect public goods provided by the agricultural activity). Finally, the support should be targeted on the active farmers (EC, 2010).

The current two-pillar system of supports should be maintained. The first pillar is the direct payments and market measures with rules clearly defined on the EU level. The second pillar is the perennial measures for rural development, where the framework for possible regimes is defined on the EU level, but the final choice is left for the member states or regions under common administration. Nevertheless, more often than not, shouts of disapproval maintain that the current policy should not be so much ecologically focused, as at is already the most ecologically-oriented policy worldwide (Agris, 2010).

By contrast, the traditional and new member states are fighting very hardly for their positions in the context of financial problems connected with the recent economical crisis, even though one of the priorities of common agricultural policy of the EU is the creation and maintaining uniform and fair European agrarian market. These strained relations are even multiplied by establishing the European budget for the year 2013 and distribution of agricultural subsidies in the upcoming planning period of years $2014-2020$.

Despite the fact that the EU as a unit emphasizes a common subsidiary system, which is valid for all members, the nominal size of direct payments, triggers a heated discussion about the injustice of the current system. It is necessary to objectively state that agrarian policy truly shows differences between traditional and new members. The size of subsidies in the countries of the original EU 15 is roughly one third higher than in the countries of EU 12, because the size of agricultural subsidies reflects different production costs in different member states and also the level of population purchasing power.

A comparison of the agricultural value added and subsidies per hectare in the countries of V4 and the Netherlands - as a country with one of the highest levels of per hectare subsidies - is shown in Table 2. This table illustrates that it is the Czech Republic that receives the highest subsidy considering the "hectare performance". On the contrary, in the Netherlands, an approximately 4.5 times higher subsidy in the absolute amount presents in relation with its value added only a little over $17 \%$ on hectare value added with subsidies. In this point of view, Slovakia and Hungary are very close. Poland is closer to the Netherlands in relative amounts, but not in absolute amounts - Poland has 5.5 times higher value added without subsidies than Czech Republic, whereas the Netherlands create 12 times higher value added without subsidies per hectare than Poland. For clarity, it is necessary to add that the commodity structure for which the land is used has significant impact on these results.

Table 2: The Comparison of the Structure of Agricultural Value Added with Subsidies Per Hectare in the States of V4 and the Netherlands

\begin{tabular}{|l|c|c|c|c|c|c|}
\hline \multicolumn{1}{|c|}{ State } & \multicolumn{2}{c|}{$\begin{array}{c}\text { Value Added without } \\
\text { Subsidies }\end{array}$} & \multicolumn{2}{c|}{ Subsidies } & \multicolumn{2}{c|}{$\begin{array}{c}\text { Value Added with } \\
\text { Subsidies }\end{array}$} \\
\hline & EUR/ha & $\%$ & EUR/ha & $\%$ & EUR/ha & $\%$ \\
\hline Czech Republic & 49 & 24 & 157 & 76 & 206 & 100 \\
\hline Slovakia & 182 & 59 & 124 & 41 & 306 & 100 \\
\hline Hungary & 211 & 60 & 139 & 40 & 350 & 100 \\
\hline Poland & 272 & 70 & 117 & 30 & 389 & 100 \\
\hline Netherlands & 3302 & 83 & 698 & 17 & 4000 & 100 \\
\hline
\end{tabular}

Source: Authors’ calculations based on Havel, 2010. 
However, application of unified subsidies would lead to such situation when for example, Czech farmers could not compete with Romanian farmers, and German farmers could not compete with Czech farmers due to the higher costs (both production costs and costs of living). That would deny the basic idea of creating common and most of all unified and self-sufficient market, which will be competitive with other world economic units. National economies would cease to act like economic-political integrated unit.

On the other hand, it is not possible to overlook the economic irrationality of these subsidies, which go against the spirit of market liberalization and are artificially sustaining entities with higher than necessary minimum costs. The reason could be found also in regional disparities of EU on the level of whole national economies.

\subsection{The EU Agricultural Policy and its Contribution to the Fulfillment of the Aims of EU Regional Policy}

From the point of view of evaluating wealth creation and agriculture performance of each country, it is possible to use the indicator of the gross value added. This indicator in its relative form to the number of inhabitants in each country illustrates the development of performance level in the agricultural sector, both in the whole EU, i.e. in the group of traditional and new member states in the Figure 1, and in each EU member state in Table 3. The data in the Figure1 and Table 3 are in basic prices which means in such prices that producers obtain after deduction of all taxes from production and after adding all subsidies on products.

Figure 1 shows the decline of agriculture performance, measured by gross value added in basic prices in the whole EU. It is obvious, that the dynamics of the EU 15 decline is decreased by the moderate trend of EU 12 decline. From Figure 1, it is obvious that the agriculture value added of traditional EU members - that means EU 15 - follows the development of the value added of whole EU, but all the time it stays above the EU average. Before the EU 12 countries entered in 2004 and 2007, they had a significantly lower produced value added per one inhabitant. The only significant improvement happened between 2003 and 2004, when the value increased from original 187 EUR to almost 231 EUR per one inhabitant. Together with the entrance of new member states, there was a significant decrease in value added of traditional countries, namely from the value over 392 EUR per one inhabitant in 2004 to 334 EUR in 2005. The agriculture performance was influenced by the crisis of 2009 in both groups, but the year 2010 should, according to the estimates, return the status to the moderate decreasing trend of previous years.

Figure 1: The Development of Gross Value Added per Capita in EU 27, EU 15, and EU 12, 2000 - 2010 (In EUR per capita; 2005 constant prices)

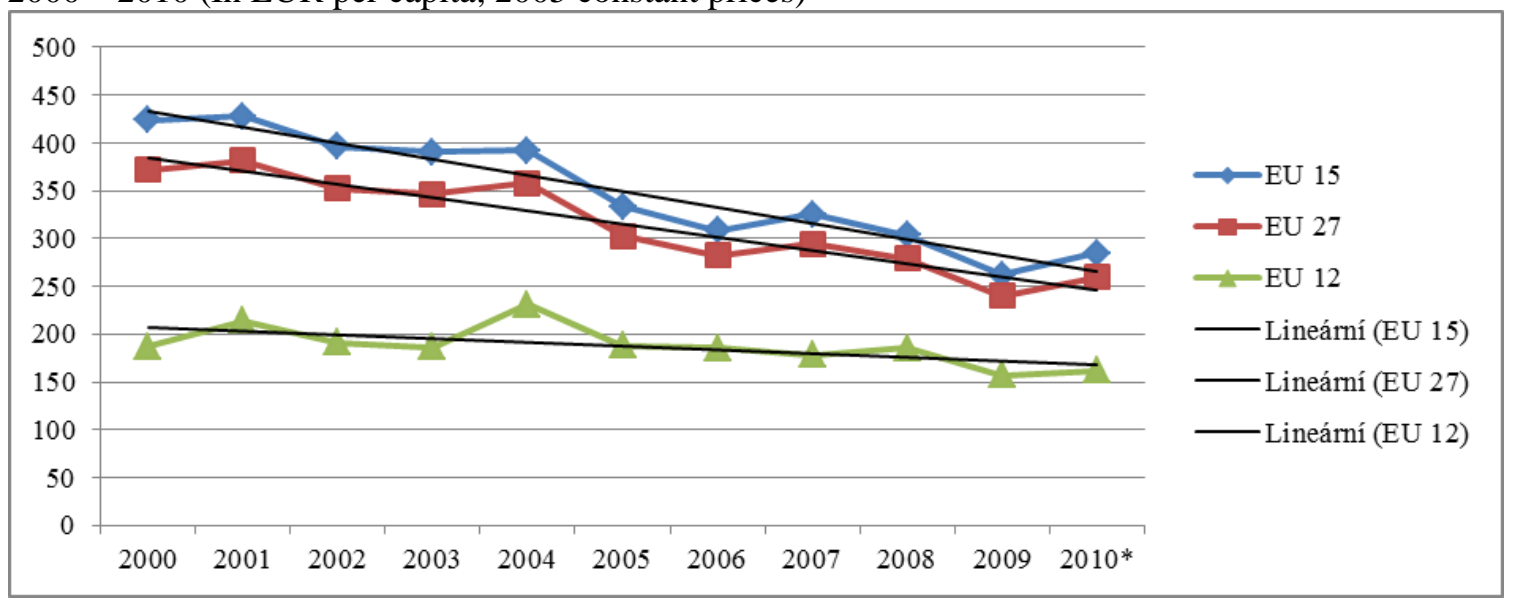

Source: Authors' calculations based on (Eurostat, 2011) data. * Estimated values for 2010. 
The values in Table 3 below are sorted according to the estimate of the indicator value in 2010. It is obvious that the total values of EU 15, EU 27, and EU 12 generally split the European countries into three groups. In the first most efficient group, the biggest decline during the period of observation affected Ireland, Greece and Denmark. In the second most efficient group, the declines are lower on average, and Poland even manifests a significant increase. In the group of the least efficient countries, including the Czech Republic, which occupies the last, but one position before Slovakia, the development varies significantly - from the $50 \%$ decrease in small Luxembourg to the slight increase in Lithuania and Estonia. (In the Czech Republic, the agriculture gross value added measured in basic prices culminated in 2002, later, after the drop in 2003, it increased in the year of entrance into the EU, and it has been showing steady decrease since 2005).

Table 3: Gross Value Added of Agriculture per Capita in EU Countries, 2000 - 2010

\begin{tabular}{|c|c|c|c|c|c|c|c|c|c|c|c|c|}
\hline Country/Year & 2000 & 2001 & 2002 & 2003 & 2004 & 2005 & 2006 & 2007 & 2008 & 2009 & 2010* & $\begin{array}{l}\mathrm{Y} 2010 / \\
\mathrm{Y} 2000 \\
\end{array}$ \\
\hline Netherlands & 675 & 611 & 545 & 552 & 507 & 505 & 553 & 535 & 464 & 415 & 504 & 0.75 \\
\hline Spain & 699 & 719 & 674 & 711 & 653 & 570 & 474 & 526 & 458 & 421 & 432 & 0.62 \\
\hline Greece & 831 & 824 & 779 & 761 & 731 & 698 & 539 & 523 & 447 & 452 & 431 & 0.52 \\
\hline France & 552 & 542 & 516 & 483 & 491 & 458 & 405 & 434 & 388 & 319 & 377 & 0.68 \\
\hline Ireland & 872 & 761 & 668 & 663 & 672 & 496 & 364 & 423 & 355 & 213 & 351 & 0.40 \\
\hline Denmark & 655 & 753 & 576 & 560 & 590 & 423 & 423 & 422 & 292 & 256 & 349 & 0.53 \\
\hline Cyprus & 543 & 588 & 580 & 542 & 468 & 444 & 387 & 358 & 328 & 344 & 347 & 0.64 \\
\hline Italy & 550 & 550 & 528 & 515 & 521 & 444 & 426 & 413 & 405 & 344 & 345 & 0.63 \\
\hline Austria & 349 & 366 & 336 & 330 & 338 & 281 & 296 & 333 & 324 & 266 & 291 & 0.83 \\
\hline EU 15 & 424 & 428 & 396 & 390 & 392 & 334 & 308 & 325 & 303 & 262 & 285 & 0.67 \\
\hline EU 27 & 372 & 381 & 352 & 347 & 358 & 303 & 283 & 295 & 279 & 240 & 260 & 0.70 \\
\hline Romani & 279 & 358 & 329 & 349 & 416 & 286 & 286 & 212 & 273 & 233 & 221 & 0.79 \\
\hline Belgium & 298 & 278 & 246 & 248 & 257 & 213 & 237 & 237 & 190 & 186 & 220 & 0.74 \\
\hline Finland & 320 & 321 & 310 & 298 & 295 & 284 & 192 & 244 & 190 & 212 & 204 & 0.64 \\
\hline Hung & 266 & 263 & 222 & 207 & 245 & 219 & 222 & 207 & 234 & 159 & 187 & 0.70 \\
\hline Portu & 285 & 296 & 268 & 270 & 274 & 227 & 228 & 188 & 183 & 180 & 180 & 0.63 \\
\hline Germ & 223 & 250 & 201 & 182 & 227 & 155 & 159 & 191 & 183 & 150 & 174 & 0.78 \\
\hline Slove & 241 & 217 & 264 & 199 & 248 & 240 & 228 & 201 & 185 & 166 & 172 & 0.71 \\
\hline Poland & 136 & 154 & 133 & 127 & 178 & 160 & 162 & 190 & 167 & 167 & 168 & 1.23 \\
\hline EU 12 & 187 & 214 & 191 & 187 & 231 & 188 & 186 & 178 & 186 & 157 & 162 & 0.87 \\
\hline Lux & 322 & 323 & 335 & 306 & 316 & 230 & 205 & 256 & 187 & 141 & 160 & 0.50 \\
\hline & 134 & 118 & 115 & 133 & 159 & 176 & 153 & 196 & 173 & 145 & 158 & 1.17 \\
\hline $\mathrm{Bul}$ & 253 & 264 & 232 & 218 & 218 & 199 & 179 & 137 & 195 & 131 & 143 & 0.56 \\
\hline Sweden & 173 & 174 & 180 & 179 & 168 & 138 & 157 & 172 & 150 & 111 & 141 & 0.82 \\
\hline Estc & 136 & 162 & 152 & 129 & 160 & 162 & 162 & 190 & 129 & 104 & 138 & .01 \\
\hline Gre & 174 & 171 & 177 & 186 & 173 & 119 & 116 & 123 & 161 & 137 & 130 & 0.75 \\
\hline Malta & 154 & 161 & 155 & 143 & 134 & 144 & 140 & 128 & 130 & 133 & 130 & 0.85 \\
\hline Lat & 86 & 102 & 100 & 104 & 126 & 121 & 123 & 117 & 87 & 66 & 82 & 0.96 \\
\hline Czech R & 113 & 126 & 99 & 93 & 134 & 98 & 92 & 105 & 94 & 56 & 74 & 0.66 \\
\hline Slovakia & 88 & 109 & 124 & 87 & 114 & 84 & 88 & 82 & 90 & 40 & 51 & 0.58 \\
\hline Minimum & 86 & 102 & 99 & 87 & 114 & 84 & 88 & 82 & 87 & 40 & 51 & 0.40 \\
\hline Maximum & 872 & 824 & 779 & 761 & 731 & 698 & 553 & 535 & 464 & 452 & 504 & 1.23 \\
\hline Variation range & 786 & 722 & 680 & 674 & 617 & 615 & 464 & 453 & 376 & 413 & 453 & 83 \\
\hline $\begin{array}{l}\text { Variation range } \\
\text { YOY change }\end{array}$ & & -64 & -42 & -6 & -57 & -2 & -150 & -11 & -77 & 36 & 41 & \\
\hline
\end{tabular}

Source: Authors' calculations based on (Eurostat, 2011) data; in EUR, at current basic prices

* Estimated values for 2010; sorted in descending order according to 2010 values 
The development of variation range shows gradually decreasing differences in the agriculture efficiency of all member states. This trend was especially valid during the period of $2000-2008$ on different levels: the lowest in the year 2005, after which the following year 2006 brought the highest decrease of variation range in the agriculture efficiency of EU member states. Unfortunately, the year 2009, as well as 2010 meant the increase of differences in evaluated indicator, but it is not yet possible to generalize it as a difference in the long-term trend.

The fulfillment of growth and convergence aims of the regional policy through the common agricultural policy does not look so optimistic in the data analysis of the last part of current planning period, namely the period of 2007 - 2010. For better imagination, Figure 2 follows, illustrating the comparison of the whole EU and several selected countries from both traditional and new EU member states. Two countries with the highest value of gross value added in 2010 were selected (the Netherlands, Cyprus), together with two having the lowest value of this indicator (Great Britain, Slovakia).

Figure 2: Gross Value Added per Capita in EU 27 and Selected Countries, 2007 - 2010

(In EUR per capita; 2005 constant prices)

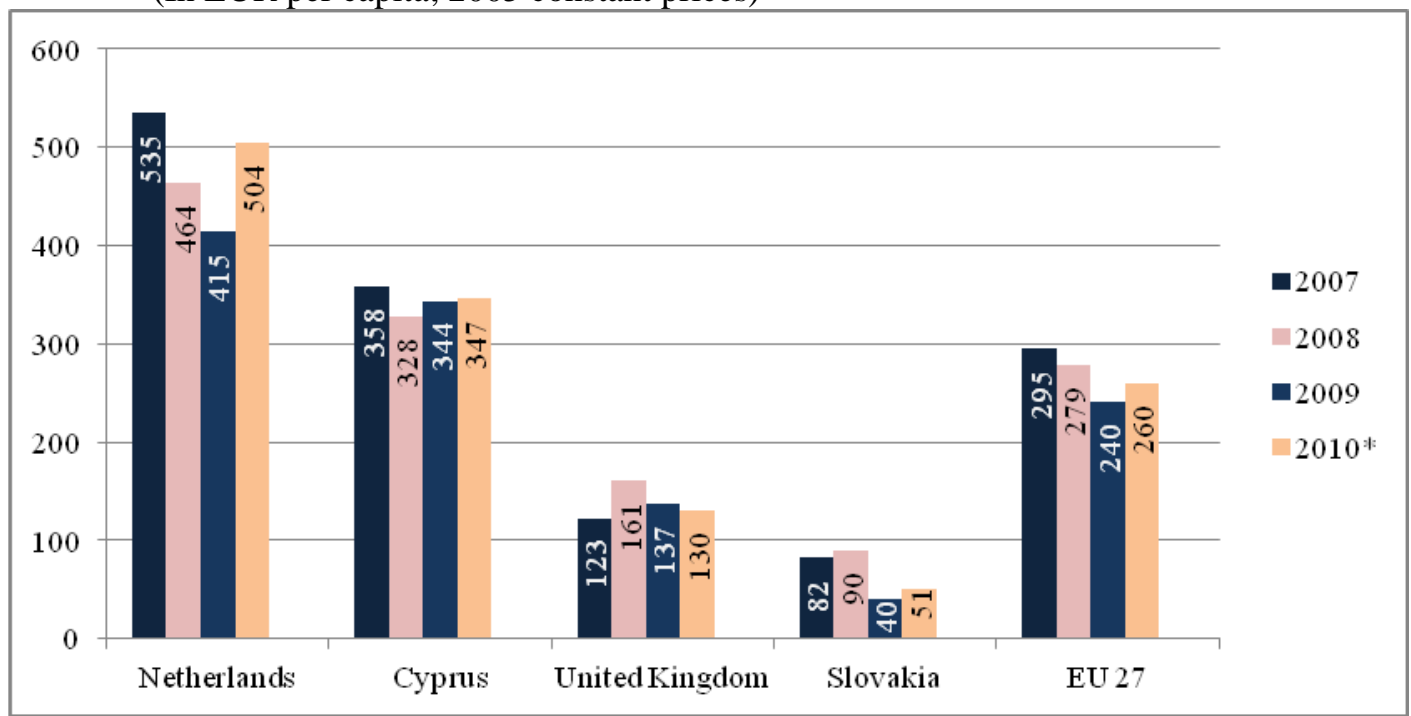

Source: Authors’ calculations based on (Eurostat, 2011) data.

Traditionally, the Netherlands has high value added within the EU 15. It is estimated on 504 EUR per capita in the year 2010, which is the highest amount in all EU 27. On the other side of the spectrum is Great Britain with the lowest amount among the traditional countries. In the past years, the figure fluctuated between 160 - 130 EUR per capita and it was even under the average of EU 12 countries. Among the new member states, Cyprus excels from this point of view, with the gross value added per capita over 346 EUR last year. In the long term, that not only exceeds the average of the whole EU, but also slightly the average of EU 15. On the other side of the spectrum is Slovakia, where the gross value added of agriculture significantly decreased in the year 2008 and in 2010, it was only 51 EUR per capita.

From the above-mentioned data, it is obvious that the size of gross value added per capita is not bound to the membership of the country in the group of traditional or new member states. By means of their performance in this respect, Netherlands is close to Cyprus on the one end, whereas Great Britain and Slovakia are close to each other on the other end. In addition, the index of growth recorded in analyzed countries during 2007 - 2010 is quite interesting. While the indexes of Netherlands (0.94), Cyprus (0.97) and Great Britain (1.06) indicate the convergence of more efficient and less efficient countries, this situation is refuted by performance-weak Slovakia, where the situation is getting significantly 
worse and where this index is only 0.62. (For completeness, the index of EU 27 was 0.88 in this period).

The question remains, whether the subsidies within the first pillar of EU common agricultural policy correlate with the agriculture efficiency of EU countries measured by gross value added per capita. The average size of direct payments was 285 EUR on 1 hectare of agricultural land in the whole EU in 2010, the average gross value added per capita was 228 EUR. In EU 15 countries it was 323 EUR/ha and gross value added 286 EUR/inhabitant, in EU 12 countries the average subsidy was 238 EUR/ha and gross value added 156 EUR/inhabitant. However, Figure 3 below illustrates a rather considerable variance of values in different countries and the regression line thus manifests a relatively low level of reliability.

Figure 3: The Relation between the Direct Subsidies and the Agricultural Gross Value Added per Capita in EU Countries, 2010

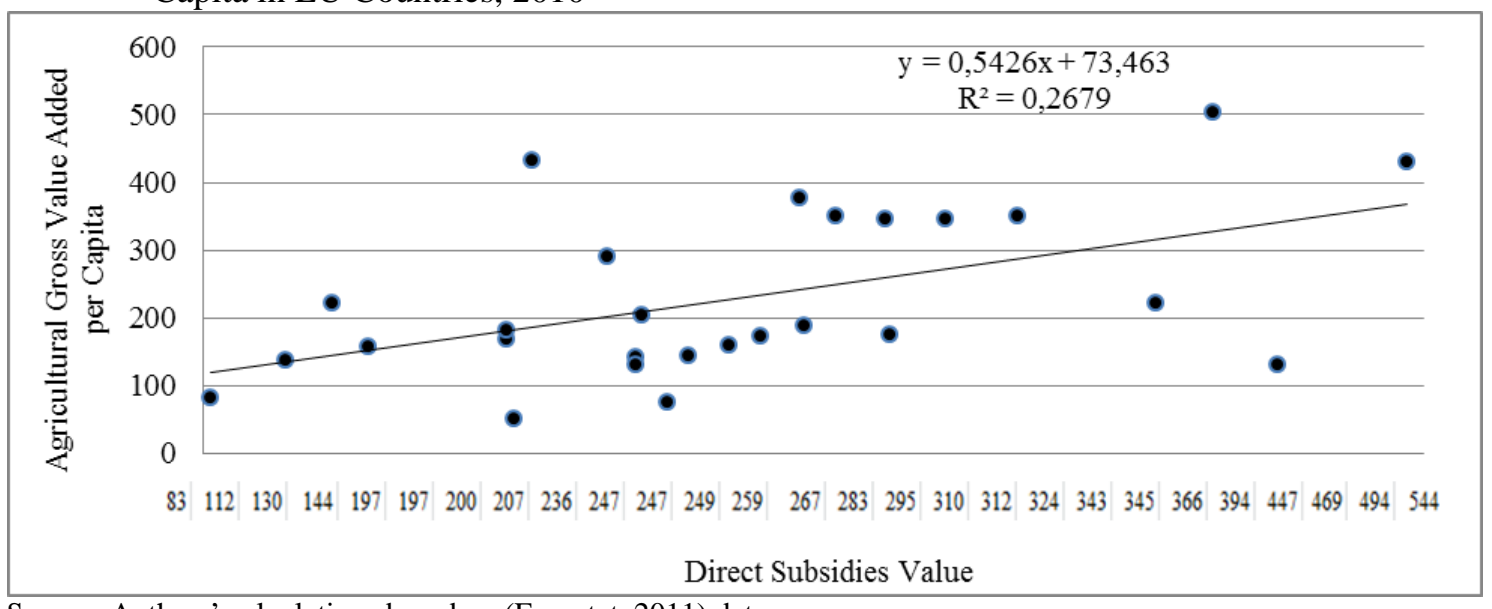

Source: Authors' calculations based on (Eurostat, 2011) data.

The degree of correlation measured by Spearman's coefficient of serial correlation on the level of significance 0.05 shows the existence of correlation dependence between both indicators. The alternative hypothesis $\mathrm{H}_{1}$ is accepted and the null hypothesis is rejected, because the value of the test criteria $r_{s}$ is equal to 0.4484 which fell into the critical area $(0.3822<0.4484)$. There is, however, the correlation dependence between the different size of provided direct payments on 1 hectare of agricultural land and the produced gross value added per capita in agriculture (Horáková, 2011).

The detected correlation relationship is the basis for the following assessment of the indicator of agricultural subsidies unit efficiency in EU in 2010. This indicator is a ratio of the amount of gross value added per capita in the agricultural sector to one unit of direct payments from the EU:

$$
U E A S_{i}=\frac{G V A_{i} / C_{i}}{D P_{i} / H_{i}}
$$

Where,

UEAS is Unit Efficiency of Agricultural Subsidies of country $i$; GVA/C is Gross Value Added per Capita of country $i$ (in EUR); DP/H is Direct Payment per Hectare of country $i$ (in EUR).

The above indicator of unit efficiency of agricultural subsidies (direct payments) does not yield positive results. As demonstrated in Figure 4, there are only nine countries with one or more EUR of gross value added per capita from one EUR of subsidies, whereas only two countries have one-and-half time amount or double amount, namely Spain and Romania. Most countries (14) have the efficiency within the interval from 0.5 to 1; Slovakia, Malta, Czech Republic and Belgium occupy the worst position of analyzed subsidies efficiency, namely less than a "half appreciation" of gross value added per capita created by subsidies, as illustrated in Figure 4. 
The average size of UEAS in the whole EU is approximately 0.86 . This value is within the interval $<0,49 ; 2,07>$ in traditional EU countries - the variation range is 1.58. By excluding Spain with its extreme value (2.07), the variation range decreases to 0.74 . The average UEAS value among the EU 15 states is 0.91 . This indicator is within the interval $<0,26 ; 1,70>$ and the variation range equal to 1.44 is slightly lower. By excluding Romania with its extreme value (1.70), the UEAS reaches the interval $<0,26 ; 1,23>$. This will decrease the variation range to 0.97 which is higher value compared to EU 15 . These countries were able to produce average of 0.77 EUR of gross value added per capita from 1 EUR of direct payment in 2010, which is after the elimination of extreme values of Spain and Romania the average of the whole EU.

From what is mentioned above, it is obvious that the differences in agricultural subsidies efficiency exist across all 27 countries of the EU. Although the EU 12 level is generally lower, this group of countries is represented in both groups - countries with the highest UEAS, as well as countries with the lowest value of this indicator. In this latter group, 3 positions out of 4 are taken by EU 12 states.

Figure 4: Unit Efficiency of Agricultural Subsidies (UEAS) in EU, 2010

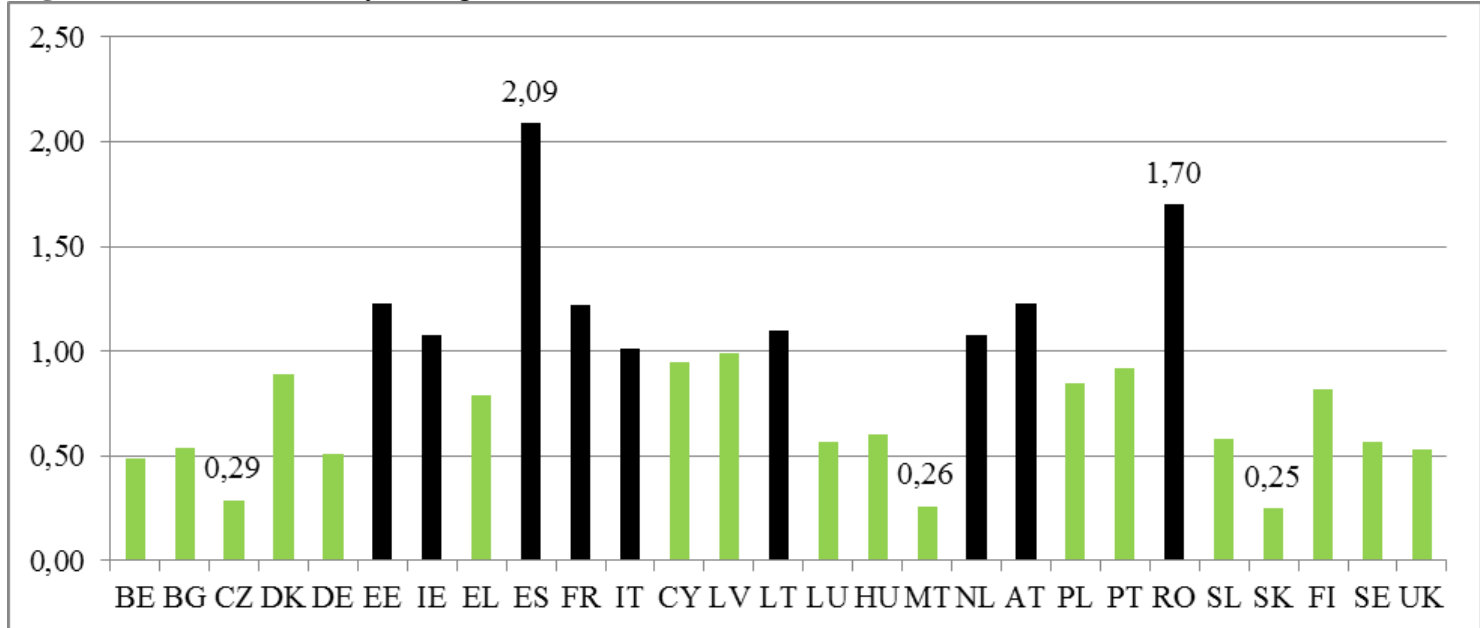

Source: Authors’ calculations based on (Eurostat, 2011) data.

Note: Color differentiation is used for countries with UEAS $<1$ (green) and UEAS $>1$ (black).

It is necessary to add to the above results that the recipients of agricultural subsidies are not only purely agricultural companies, which means that the gross value added of these recipients is recorded in the sector where these companies belong. In the Czech Republic, for instance, besides the purely agricultural companies there are also companies far removed from agricultural or food industry on the list of agricultural subsidies recipients and they receive payments for grounds, draw export subsidies, or supports for rural development nonetheless. Nestle, Coca-Cola, PepsiCo or Wrigley represent some of these companies, but there are also chemical companies, such as Borsodchem from Ostrava, which received the total subsidy of 66.5 million CZK, or two football clubs from Olomouc, which received the subsidy of 380 million CZK from the program for rural development (Králová, 2010).

\subsection{The Direction of the Agricultural Efficiency in the Interest of Cohesion Regional Policy}

The prices of commodities development, as well as the agricultural and regional EU policies in the incoming planning period after 2013 are important for the next development of European agriculture and its influence on the development of agricultural regions, which is reflected also in their efficiency during the creation of wealth. 
The prospective situation in agriculture prepared by OECD focused on the period $2009-2018$ and it expected the weakening of economy accompanied by low prices of commodities in the period 2009 2011. In the following years, average real prices (modified by inflation) could be expected, on the level of prices before 2007. Considering the high incomes of agricultural producers and relatively independent demand for food, the immunity of agricultural sector against the impacts of economic recession could be expected in the future. According to the FAO prediction concerning the development of both population and incomes, it "... will be necessary to increase the global production of food by more than $40 \%$ until 2030 and more than $70 \%$ until 2050" (OECD-FAO, 2009). Moreover, FAO presents that due to increasing productivity of both plant and animal production - in the most productive areas at least -a significant potential for the increase in production can be found for the upcoming $10-20$ years. It will assume using new and existing technologies and also the support of agricultural research by public expenditures. Despite the relatively positive agriculture view in the sector of agricultural commodities, the disturbing news about the long-term problem of both poverty and hunger alleviation of approximately one billion people will still persist. Although hunger does not appear to be a problem directly for the European population, EU is concerned with the above-mentioned situation. International trade with agricultural production is connected with high transaction costs, which could also be the reason for intended direction of common agricultural policy in the upcoming planning period.

This direction is made in three variants, but in principle brings nothing new. All variants differ more or less in the level of regulation of all three areas (Businessinfo, 2010), (EC, 2010):

a) Direct payments - from the requirement of preserving the current system with the appeal on the more equitable distribution of direct payment among member states, over the preserving of direct payments, but with new structured construction (basic rate + obligatory additional support + additional compensation payment + voluntary support linked to production), to gradual abolition of direct payments and their replacement with limited payments for environmental public goods and additional payments for special natural constraints;

b) Market measures - from the strengthening of management tools, over the improvement and simplification of market tools (but only where appropriate), to the proposal of the cancellation of all market measures (with the possibility of application of the clause in case of serious crisis);

c) Rural development - from the proposal of increased financing of relatively wide spectrum of problems (the climatic and water changes, biodiversity, energy from renewable sources, and innovations), over simple adaptation and supplement of tools in such a way which is consistent with EU priorities and strengthening regional and local initiatives with possible resources redistribution among member states, to the focus mainly on fight against the climatic changes and on the environmental questions.

On October 12th 2011, European Commission introduced a set of legal proposals designed to make common agricultural policy a more effective policy for a more competitive sustainable agriculture and rural areas for the period after 2013. However, this proposal has been multilaterally criticized. The most criticized part is the one dealing with the so-called greening. According to the proposal, $30 \%$ of direct payments should be conditioned by fulfilling three following requirements: maintaining perennial vegetation, crop rotation of the cultivated land, and maintaining at least $7 \%$ of the agricultural land in uncultivated state (EC, 2011a). An issue of particular concern is, among other things, the high burden of bureaucracy for farmers. Another heavily debated issue is the one of "injustice" of the subsidies for the new member states in comparison to the original EU 15. Moreover, what poses a problem for the Czech Republic is the proposed "roofing" of big farms, because there are numerous big agricultural businesses in this country transformed from the former socialist Uniform Agricultural Cooperative. OECD also reacts on the new proposal of common agricultural policy and its study strongly emphasizes that there is a significant share of support for farmers with high incomes. The author's state that even the lower amount of funds could be more beneficial, provided that the support is properly addressed (OECD, 2011). 


\section{CONCLUSION}

Agricultural subsidy policy has been a widely debated issue. It is one of the most important tools of national, European and world politics in their achieving established goals. There are both opponents and proponents of this policy, both in laic and professional communities.

The first group emphasizes that agriculture is the same business sector as the other sectors and that state does not support these other sectors by subsidies. Agriculture is also based on private ownership, not the state one, which means that the owners are farming, not the state, and, in addition, agricultural subsidies disproportionately burden the taxpayers.

The proponents of agricultural subsidies point in particular on the specificity of this sector of economy. The lack of profitability is attributed more to the objective factors than to the subjective reality, and the necessity of subsidies is justified by the threat of negative consequences for the whole economy.

The dimension of EU agricultural policy is proofed by the status in the European budget framework, where it was almost $90 \%$ in 1970, and it has been only around $40 \%$ in several past years, with parallel absolute increase of provided supports. The issue of agricultural subsidy policy is reflected also in the number of reforms, which it underwent. The focus of the first reform on the efficiency increase of each active farmer from 1968 "remained in action" for the longest period of time, almost the quarter of the century. The reforms have continued in five to six-year interval since 1992, and their focus declares the orientation on both the increase of farmers' incomes and maintaining "reasonable" price ratios. The rural development was already anchored in the MacSharry's reform from 1992. By adjusting the modulation principle in 2003, the amount of resources provided not to purely agricultural farmers, but to the rural development as such, increased to the current $10 \%$ of financial resources dedicated to farmers’ support.

It is possible to claim that there is no business area more regulated and administratively bound than agriculture. This is, among other things, a result of a relatively complex system of agricultural supports stemming from the basic goal in Europe - the massive support of production of raw materials to the food production. Nowadays there are two basic cornerstones - production (the sector development) and rural support (the region development). It seems that current discussion about new "more justified" distribution of allocated amounts among the member states has its substantiation; that the fixed amounts from the nineties are significantly diverged from the reality.

The conducted research has shown that the agricultural subsidy policy helps, to some degree, to fulfill the aims of cohesive regional policy, not only due to the target rural development programs, but also due to its support of agricultural production.

The results show that:

- the variation range in the agricultural efficiency of member states is decreasing;

- by dividing the countries into three groups - where the values for the distribution in the long-term achieved efficiency are the average values of EU 15 and EU 12 - it is possible to see that there are states from both groups in all three categories, while the most numerous representation of countries from both groups has the third of countries of moderate efficiency;

- the example of the development of two of the most efficient and two of the less efficient countries in the first four years of the current planning period illustrated the superiority of convergent trends;

- it has been shown, that there is a correlation relationship between the size of direct payments and the level of gross value added;

- the unit efficiency of agricultural subsidies is quite problematic - 2/3 of EU 27 countries have valorized the subsidies per hectare at the level lower than " 1 " which means that gross value 
added per capita does not reach even 1 euro for each 1 euro of subsidy per hectare; nevertheless, there are 2 most extreme maximal values and 3 most extreme minimal values which means there is no significant variability in subsidies efficiency; moreover, there are both traditional and new member states in both extreme values.

The last mentioned result evokes again the economical considerations about immanent non-efficiency of public sector, namely of resources redistributed by public sector. The market imperfection in the area of agriculture solved by financing of "non production" is nonsense in the context of global poverty problem. The directing of the amounts on the rural support by modulation seems to be adequate tool for increasing the socio-economic level of rural regions; the question is whether these amounts should be presented as a tool of agricultural or regional policy.

As a global player Europe is weaker in many respects, its position being overtaken by rapidly growing Asia. Can Europe remain in growing inefficient allocation of financial resources under the circumstances? Is it not dangerous for the future development of EU to prefer the cohesion policy instead of growing tools of European integration groupings? We are facing the task to set the tools of EU strategic management correctly by 2020 , with the aim of "an intelligent and sustainable growth supportive of incorporation". However, a question remains to be answered, whether to prefer an intelligent and sustainable growth, or accentuate the growth supporting the incorporation in the interest of cohesion of the European regions. This is a very general question, yet the range of current financial support of agricultural and regional policy indicates that these two elements of European integration should reflect the current trends of globalized economy.

\section{ACKNOWLEDGEMENTS}

This article was made with the support of research project IGA of University of Pardubice SGFES01/2011, a part "Factors of Growth and Development of Mesoeconomy in the Context of EU 2020 Strategy". The authors would also like to thank Pavlína Horáková for assisting in data collection and processing.

\section{REFERENCES}

Agris (2009). Př́mé platby SPS, SAPS...co to vlastně je? (The Direct Payments SPS, SAPS ... What Is It Actually?) Available at WWW:

$<$ http://www.agris.cz/zemedelstvi/detail.php?id=162818\&iSub=524>. [Accessed 2011-03-24].

Agris (2010). Stanovisko Zemědělského svazu ČR ke sdělení Evropské komise (The Opinion of the Agricultural Association of the Czech Republic on the European Commission Communication). Available at WWW: <http://www.agris.cz/podnikani/detail.php?id=169155\&iSub=598>. [Accessed. 2011-03-25].

Bureš, J. (2004). Nová rozpočtová perspektiva - velké klubko sporů a zájmi̊ (New Budgetary Perspective - The Large Ball of Disputes and Interests). Available at WWW: $<$ http://www.europeum.org/en/>. [Accessed 2010-12-14].

Businessinfo (2010). Komise představuje plán pro perspektivní společnou zemédělskou politiku po roce 2013 (The Commission Presents the Plan for Perspective Common Agricultural Policy after 2013). Available at WWW:

<http://www.businessinfo.cz/cz/clanek/aktuality-z-eu-listopad-2010/ek-plan-spolecna-zemedel-p olitika-2013/1001934/58975/>. [Accessed 2011-03-22].

EU-Media (1999) . Reformy společné zemédělské politiky (Common Agricultural Policy Reforms). Available at WWW:

<http://www.euractiv.cz/zemedelstvi0/link-dossier/reformy-spolen-zemdlsk-politiky>. 
[Accessed 2010-12-12].

EC - European Commission (2004). New perspectives for EU rural development. Germany: White Chlorine-Free Paper, 2004. Available at WWW:

$<$ http://ec.europa.eu/agriculture/publi/fact/rurdev/refprop_en.pdf>. [Accessed 2010-12-14].

EC - European Commission (2010). The common agricultural policy after 2013 - Agriculture and rural development. Available at WWW:

$<$ http://ec.europa.eu/agriculture/cap-post-2013/index_en.htm>. [Accessed 2011-03-22].

EC - European Commission (2011a). Legal proposals for the CAP after 2013. Available at WWW: $<$ http://ec.europa.eu/agriculture/cap-post-2013/legal-proposals/index_en.htm>. [Accessed 2011-11-04].

Eurostat (2011). Eurostat Data Explorer 2011. Available at WWW:

$<$ http://epp.eurostat.ec.europa.eu/portal/page/portal/statistics/search_database>. [Accessed 2011-04-06].

EK - Evropská komise / European Commission / (2010). Zemědělství a rozvoj venkova. Společná zemědělská politika (The Agriculture and Rural Development. Common Agricultural Policy). Available at WWW: <http://ec.europa.eu/agriculture/capexplained/index_cs.htm >. [Accessed 2010-12-13].

ES - Evropské společenství /European Community/ (1957). Římská smlouva 1957 (The Treaty of Rome 1957). Available at WWW:

$<$ http://www.mfcr.cz/cps/rde/xbcr/mfcr/Rimska_smlouva_1957.pdf >. [Accessed 2010-12-13].

Havel, P. (2010). Stejné platby na plochu pro všechny zemédělce v EU jsou iluzi (The Same Payments on the Area for All Farmers in EU Are Illusion). Available at WWW:

$<$ http://www.agris.cz/detail.php?iSub=518\&id=166513 >. [Accessed. 2011-03-23].

Horáková, P. (2011). Analýza odvětví zemědělství (The Analysis of the Agricultural Sector). Thesis. Pardubice : University of Pardubice, 2011.

Kaplan, M. (2008). Rozvojová politika vyspělých zemí (OECD/DAC) (The Development Policy of Developed Countries (OECD/DAC)). Available at WWW:

$<$ http://www.rozvojovka.cz/rozvojova-politika-vyspelych-zemi-oecd-dac_228_4.htm >. [Accessed 2010-12-19].

Králová, T. (2011). Hausnumera a osobní vazby. Tak se rodí dotace. (“Huge Numbers” and Personal Relationships. That Is the Way How Subsidies Are Born.) Available at WWW:

$<$ http://www.vlasak.net/novinka/1495 >. [Accessed 2011-04-25].

Králová, T. (2010). Kdo zobe dotace z evropského dvorku: Nejvíc spolkne Babišovo impérium, penize berou i světovi giganti, hlídači a fotbalisté (Who Is Pecking the Subsidies from the European Yard: The Biggest Part Is Going to the Empire of Babiš, Money Is Going Also to the World's Giants, Watchmen and Footballers). Available at WWW:

$<$ http://www.euro.cz/id/1rycehbggcizm1h6s5st4g8hgd/seznam.jsp?id=10\&typ=20\&value=-1\&de $\mathrm{f}=1>$. [Accessed 2011-04-14].

Kučera, J., Štolbová, M. (2010). Metodika aplikace společných kritérii EU pro redefinici LFA v podminkách $\check{C} R$ (The Methodology of Application of Common EU Criteria for Redefinition of LFA in the Conditions of Czech Republic). Available at WWW:

$<$ http://www.uzei.cz/left-menu/publikacni-cinnost/metodiky/Metodika-LFA.pdf>. [Accessed 2010-12-19]. 
MZ - Ministerstvo zemědělství /Ministry of Agriculture/ (2010). Vznik, vývoj a reformy Společné zemédělské politiky (The Formation, the Development, and the Reforms of Common Agricultural Policy). Available at WWW:

$<$ http://eagri.cz/public/web/mze/ministerstvo-zemedelstvi/zahranicni-vztahy/cr-a-evropska-unie/ vznik-vyvoj-a-reformy-pravidel-szp/vznik-vyvoj-a-reformy-spolecne.html>. [Accessed 2010-12-14].

Moussis, N. (2008). Access to European Union: law, economics, policies. 17th ed. Belgium, Rixensart : European Study Service.

OECD-FAO (2009). Agricultural Outlook Database 2010. Paris, France : OECD publishing.

OECD (2010). Producer and Consumer Support Estimates database. Available at WWW: $<$ http://www.oecd.org/document/59/0,3343,en_33873108_33873325_39551355_1_1_1_1,00.ht ml\#summary $>$. [Accessed 2010-12-19].

OECD (2011). Zhodnocení reformy zemédělské politiky v EU (The Evaluation of Reform of Agricultural Policy in EU). Available at WWW:

<http://www.oecd.org/dataoecd/22/30/48937654.pdf>. [Accessed 2011-11-04].

PIGP /Prague Institute for Global Politics/ (2010). SZP EU. Available at WWW:

$<$ http://www.respektinstitut.cz/wp-content/uploads/prilohy/SZP_EU.pdf>. [Accessed 2010-12-13]. 